\title{
The many roads to infection imaging
}

\author{
Mick Welling • Marcel Stokkel • Jenny Balter • \\ Laure Sarda-Mantel • Alain Meulemans • \\ Dominique Le Guludec
}

Published online: 11 January 2008

(C) The Author(s) 2007

\section{Dear Sirs,}

With great interest, we read the short comment of Giovanni Lucignani about infection imaging [1]. Here, commentaries are given, derived from a literature search including summaries of recently published articles. An important part of the publication was dedicated to the labelling of living bacteria with antimicrobial agents, mainly to the application of radiolabelled antibiotic ciprofloxacin for the specific detection of bacteria. Dr. Lucignani stated; "that the approach with technetium-labelled ciprofloxacin showed considerable promise in the preliminary studies but clinical trials have shown limitations".

On the contrary, most pre-clinical studies have shown poor specificity of technetium-labelled ciprofloxacin for bacterial infections [2-7] and vivid discussions related to this topic took place $[8-10,17]$. One of the most tested radiolabelled ciprofloxacin is Infecton ${ }^{\circledR}$ (Draximage, Quebec, Canada).

\section{Welling $\cdot$ M. Stokkel}

Department of Radiology, Section of Nuclear Medicine, Leiden University Medical Center (LUMC),

Leiden, The Netherlands

\section{J. Balter}

Centro Investigaciones Nucleares, University of the Republic Uruguay,

Montevideo, Uruguay

L. Sarda-Mantel $\cdot$ A. Meulemans $\cdot$ D. Le Guludec AP-HP, Groupe Hospitalier Bichat-Beaujon,

Service de Médecine Nucléaire,

Paris, France

\section{Welling $(\square)$}

Albinusdreef 2,

Leiden, Zuid-Holland $2300 \mathrm{rc}$,

The Netherlands

e-mail: m.m.welling@lumc.nl
This compound was evaluated in the International Atomic Energy Agency (IAEA, Austria, Vienna) sponsored study of more than 500 patients and specificity was claimed for bacterial infections [11]. However, related to its specificity, other studies showed contradicting results in pre-clinical [2-7] and clinical settings as well [12]. Although it was suggested that this was due to sub-optimal labeling conditions and sample preparations, such statements could be easily refuted by routine radiochemical analysis and biodistribution studies in laboratory animals. More recently, claims for Infecton ${ }^{\circledR}$ in its specificity for detecting of bacterial infections in humans (depending on the discrepancy between early and late imaging) was refuted as well by Palestro et al., as his group conducted a Phase II trial sponsored by Draximage, the manufacturer of Infecton ${ }^{\circledR}$, and they experienced that this tracer disappeared from sites of infection as well as from inflammation with equal rapidity [13]. As Infecton ${ }^{\circledR}$ shows detection of bacterial infections with poor specificity and accuracy [14], this group seriously considered that it is unlikely that radiolabelled antibiotics will ever be a viable method for imaging infection. Moreover, the recent press release from Draximage clearly stated that formulation development of Infecton ${ }^{\circledR}$ targeting orthopaedic indications has, to date, not been successful and Draximage will allocate the resources devoted to this product to other projects (http://www. draxishealth.com/pdf/Draxis_Q3_PR_US_GAAP.pdf). These findings are supported by two recent studies in which for synthetic ${ }^{18} \mathrm{~F}$-ciprofloxacin, no specific binding to bacteria was observed [15] and poor retention of this tracer in bacteria-infected tissues in patients [16]. These findings raise concerns about the specificity of radiolabelled antibiotics, especially for Infecton ${ }^{\circledR}$, for the detection of bacterial infections. The issue of whether the uptake is not more than a blood pool effect or the non-specific penetration 
of radiolabelled ciprofloxacin through membranes of bacterial and mammalian cells as well may explain the conflicting findings [17, 18]. The rapid introduction of Infecton ${ }^{\circledR}$ in clinical settings may pointing out the necessity of the support of pre-clinical data and the analysis of radiochemical structure for any new radiochemical tracer dedicated to the detection of bacterial infections in clinical practice.

Open Access This article is distributed under the terms of the Creative Commons Attribution NonCommercial License which permits any noncommercial use, distribution, and reproduction in any medium, provided the original author(s) and source are credited.

\section{References}

1. Lucignani G. The many roads to infection imaging. Eur J Nucl Med Mol Imaging 2007;34(11):1873-7.

2. Welling MM, Paulusma-Annema A, Balter HS, Pauwels EKJ, Nibbering PH. Technetium-99m labelled antimicrobial peptides discriminate between bacterial infections and sterile inflammations. Eur J Nucl Med 2000;27(3):292-301.

3. Welling MM, Lupetti A, Balter HS, Lanzzeri S, Souto B, Rey AM, et al. Tc-99m-labeled antimicrobial peptides for detection of bacterial and Candida albicans infections. J Nucl Med 2001;42 (5):788-94.

4. Siaens RH, Rennen HJ, Boerman OC, Dierckx R, Slegers G. Synthesis and comparison of Tc-99m-enrofloxacin and Tc-99mciprofloxacin. J Nucl Med 2004;45(12):2088-94.

5. Alexander K, Drost T, Mattoon JS, Kowalski JJ, Funk JA, Crabtree AC. Binding of ciprofloxacin labelled with technetium Tc $99 \mathrm{~m}$ versus Tc-99m-pertechnetate to a live and killed equine isolate of Escherichia coli. Can J Vet Res-Revue Canadienne de Recherche Veterinaire 2005;69(4):272-7.

6. Sarda L, Saleh-Mghir A, Peker C, Meulemans A, Cremieux AC, Le Guludec D. Evaluation of Tc-99m-ciprofloxacin scintigraphy in a rabbit model of Staphylococcus aureus prosthetic joint infection. J Nucl Med 2002;43(2):239-45.

7. Sarda L, Cremieux AC, Lebellec Y, Meulemans A, Lebtahi R, Hayem G, et al. Inability of Tc-99m-ciprofloxacin scintigraphy to discriminate between septic and sterile osteoarticular diseases. J Nucl Med 2003;44(6):920-6.

8. Pauwels EKJ, Welling MM, Lupetti A, Paulusma-Annema A, Nibbering PH, Balter HS. Technetium-99m labelled antimicrobial peptides discriminate between bacterial infections and sterile inflammations - reply. Eur J Nucl Med 2000;27(12):1866-8.

9. Pauwels EKJ, Welling MM, Lupetti A, Nibbering PH, Pauwels EKJ. Concerns about Tc-99m-labelled ciprofloxacin for infection detection—reply. Eur J Nucl Med 2001;28(6):781.

10. Pauwels EKJ, Welling MM, Nibbering PH, Lupetti A, Balter HS. Tc-99m-labeled antimicrobial peptides for detection of bacterial and Candida albicans infections - reply. J Nucl Med 2002;43(8): 1126-7.

11. Britton KE, Wareham DW, Das SS, Solanki KK, Amaral H, Bhatnagar A, et al. Imaging bacterial infection with $99 \mathrm{mTc}-$ ciprofloxacin (Infecton). J Clin Pathol 2002;55(11):817-23.

12. Dumarey N, Blocklet D, Appelboom T, Tant L, Schoutens A. Infecton is not specific for bacterial osteo-articular infective pathology. Eur J Nucl Med Mol Imaging 2002;29(4):530-5.

13. Palestro CJ, Love C, Miller TT. Diagnostic imaging tests and microbial infections. Cell Microbiol 2007;9(10):2323-33.

14. Palestro CJ, Love C, Capriolo R, Marwin SE. Phase II study of $99 \mathrm{mTc}$-ciprofloxacin uptake in patients with high suspicion of osteomyelitis. J Nucl Med 2006;47(Suppl 1):P152.

15. Zijlstra S, Gunawan J, Freytag C, Burchert W. Synthesis and evaluation of fluorine-18 labelled compounds for imaging of bacterial infections with pet. Appl Radiat Isotopes 2006;64(7): $802-7$.

16. Langer $\mathrm{O}$, Brunner $\mathrm{M}$, Zeitlinger $\mathrm{M}$, Ziegler $\mathrm{S}$, Muller $\mathrm{U}$, Dobrozemsky $G$, et al. In vitro and in vivo evaluation of [F-18] ciprofloxacin for the imaging of bacterial infections with PET. Eur J Nucl Med Mol Imaging 2005;32(2):143-50.

17. Welling MM, Nibbering PH, Paulusma-Annema A, Hiemstra PS, Pauwels EKJ, Calame W. Imaging of bacterial infections with Tc99m-labeled human neutrophil peptide-1-reply. J Nucl Med 2000;41(12):2100-2.

18. Gemmel F, Dumarey N, Palestro CJ. Radionuclide imaging of spinal infections. Eur J Nucl Med Mol Imaging 2006;33(10): $1226-37$. 